\title{
「液体誘電体の帯電と産業応用」 特集号の編集に寄せて
}

\author{
特集号編集担当

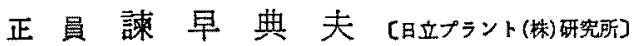

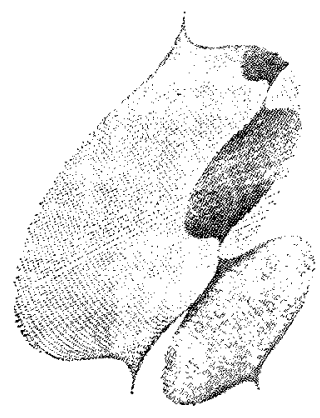

静電気現象の産業とのかかわりには，大別して有用 性のある成用 (Useful applications) と障害 (Hazards）対策亡がある。例えば，前者の代表例としては 従来からの伝珫的な産業分野である諸重化学工業, 火 力発電や都市しん加い焼却処理などにおける排湮中の 浮道粒子状物質の除去浄化のための電気集しん技術, 自動車や家電品に代表される大量生産ラインに使用さ れる静電叙装・治着技術あるいは情報機器に棜ける静 電複写・プリンタ技術などが挙げられる。また後者の 代丧例としては，石油系液体原料・製品や小麦などの 款物粉粒体の大量バルクハンドリング・輸送・眝藏時 におりる静電着火爆発などが挙げられることはよく知 られているとおりである。

最近，てれらに加えて新しく台頭してきた産業分 野, 例えばマイクロエレクトロニクス, バイオ，新素 材や俗化言われている制品の軽溥短小化, 省エネ・省 盗源化の流れに伴って，新しい静電汥術応用や静電気 障害対策の研究開発が注目されている。例えば，超小 形の静電気駆動マイクロアクチニエータを備えた IC, 異種生体細胞を電気泳動作用で相互付着させた後， の接触面の細胞膜をパルス静電界で局部麻㾝させ融合 させる逥伝子注入操作技術，Mbit 超 LSI の製造工程 や使用時に打りる静電気障害, エレクトレット化機能 プラスチックの利用技術少るいは電気流体力学 (EHD : Electro-hydro Dynamics) を利用した物質移 動・熱伝達の促進などがある。

そとで，今回はこれらの中から液体誘電体の带電に 関連する，今後興味ある産業応用として期待される四 つの題目を取上げ特集解説としたものである。まず，

「熱輸送媒体中の笔気流体力学的現象による熱伝達促 進」は，発電や冷暖房のヒートサイクルにおける熱輸 送媒体の蒸発・㠜綰過程にこれを応用すれば，熱交换 器の小形化と軽量化とが図れるはずであり大きなメリ ットが期待でるるか，いまだ商業的には実用化されて はいないので, この原理と問題点や研究開発状沉など
について解説していただいた。次に，「純水・超純水 の噴筇・接触・流動帯電とその制御」は，LSI などの 製造前段隋工程では超純水による洗浄操作の祭に発生 する静電気により障害が発生し問題となるので, 炭酸 ガス注入により電気抵执率を低下させててれを防止し ているが，重要な課題にもかかからず，てれに関する 学術諭文は皆無に近く，との現場的に対策が先行して いる技術や現像を体系的化解明する必要があると思わ れたので，その現状などについて解説をお碩いしたも のである。また，「僌犋油・絶縁油などの流動带電之 障害低隇対策」は，当学会でも従来加ら比較的, 多く の論文が発表されており長い歴史をもつ課題である が、十分に解明しつくされているとはいまだ言えな い。例えば，計画・設計の段階で流動带電量を使用条 件に忘して定量的に的確に予測したり，带電防止添加 剤の適正量を決定することは必ずしも容易ではない上 うである。そてで，てれに関して特に界面吸着電荷に 着目して最近の状況上問題点などについて解説してい ただいた。また最近，都市下水処理の際に大量に発生 する活性污泥の脱水汇，従来の機械的方法汇替えて電 気漫透法を利用することが試みら机ているが，乙の場 合, 界面吸着䉓荷に着目した本解説の考元方がその省 工ネ脱水の改善にも役立つととが考えられる。最後 に,「静電乳化・分散法の筀料・食品工業への応用了 は, 界面電気化学的な静電気現象が実際の製品の機能 や品質にどのようなかかわりをあっているのか, 最近 の現状之問題点などについて解説していただいだの で，従来，当学会にはあまりなじみのない典型的な境 界領域的な課題であるが，今後の重要な産業分野の一

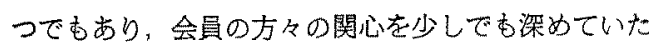
だければ幸いと期待しているものである。

とのはか，本特集の関连記事が学界情報，技街開発 レポート，資料コーナー招よび研究グループ紹介にも それぞれ揭載されているので，てれらす参照していた だければ幸いである。（昭和63 年 2 月 26 日受付） 